\title{
OPOMÍJENÝ RYCHLOOBRÁTKOVÝ KRUH LOUKOŤOVÉHO TYPU
}

\author{
PAVEL MACKU゚
}

\begin{abstract}
Abstrakt: Hrnčiřský kruh loukot’ového typu tvoři v domácím badatelském archeologickém a etnografickém prostředi dosud prehliženou složku. Jeho užiti lze prokázat již od 13. století, přičemž se v některých, převážně asijských zemich použivá v různých modifikacích doposud. Pro potreby experimentálního ověrení výroby keramiky byla vyrobena volná replika kruhu, poukazující na možnosti tvorby nádob stímto specializovaným mechanismem. Experiment poukázal mj. na problematiku konstrukčně-technického řě̌ení kruhu, a proto předložená práce $v$ hrubých rysech popisuje i navazujicí řemeslná odvětví, jako jsou kolářství či kolomaznictví.
\end{abstract}

Klíčová slova: hrnčǐrský kruh - loukot’ové kolo-experiment.

\section{The fast-turn potter's wheel of the spoked type: a marginalised subject}

Abstract: The potter's wheel of the spoked type is an element that has so far been somewhat marginalised in the Czech archaeological and ethnographic research environment. Its use goes back to the 13th century, and in some Asian countries it has been employed to this day, albeit in various modifications. A near replica of this type of the potter's wheel was made for experimental purposes testing the production of pottery, demonstrating the possibilities of the manufacture of vessels with the use of this special mechanism. The experiment brought to light problems connected with the construction and technical style of the wheel; the article thus also briefly describes related crafts such as wheel-making and axle-grease production.

Key words: potter's wheel-spoked wheel-experiment.

Keramické fragmenty, případně celé nádoby jsou nejčastěji nalézaným archeologizovaným artefaktem dokládajícím řemeslné schopnosti a um našich předků. Není proto divu, že se keramice jako takové a technologii její výroby věnuje množství prací a studií (např. Nekuda-Reichertová 1968, 33-39; Orton-Tyers-Vince 1993; Shepard 1956 aj., a to včetně knih „,hobystických“: Chavarria 1996). Patří k nim i studie zabývající se jednotlivými typy hrnčířských kruhů, odpozorovanými z etnografických a historických pramenů, mnohdy ověřovanými experimentálně. Archeologické nálezy hrnčířských kruhů ze středověkého období jsou takřka nulové. Jediný fragment ručního raně středověkého kruhu ze slovanského prostředí byl nalezen v Polsku na Ostrowě Lednickém (Kara-Wresiński 1996, 160-162). Ze západní Evropy byl publikován exemplář z Německa (Bergmann 1993, 31-39).

V české odborné literatuře se pro období stř̌edověku ustálila představa o užívání dvou druhů kruhů - pomaluobrátkových otáčených rukou a rychloobrátkových roztáčených nohou, s různými modifikacemi (naposled např. Hlavica-Nosek-Valášková-Petř́ik 2016; zde vybrané typy na obr. 1). Obecně byl mezi rychloobrátkové kruhy řazen, a nebyl tudíž blíže zkoumán, další typ kruhu, který bychom mohli vzhledem k jeho konstrukci nazvat kolovým či př́ímo loukot’ovým, roztáčeným primárně tyčí. Jinak je tomu $\mathrm{v}$ dalších státech Evropy a především sousedním Rakousku, kde je mu věnováno více prostoru v obsáhlé práci A. Kaltenbergerové (2009, 180-181, 318-322, Abb. 128-140), v Německu např́íklad v článku C. Letermové (2008), ve Francii např́íklad v díle R. Guadagnina (2007), př́ípadně se s jeho rekonstrukcemi pracuje v rámci experimentálních projektů či workshopů (např. stavba hradu Guédelon a jeho řemeslné zázemí ve Francii, viz Martin-Renucci 2016). Jedinou výjimkou z našeho prostředí je kapitola o kruzích $(1956,99-103)$ v „bibli“ československého hrnčířství od P. Rady, v níž jsou však reflektovány až loukotové kruhy etnograficky doložené z 20. století (viz dále).

Loukotový kruh spadá do kategorie specializovaných hrnčířských nástrojů vytvořených pro vytáčení keramiky především za vysokých otáček. Skládá se z nosné osy tvořené tyčí usazenou kolmo do země a na ní usazeného vytáčecího setrvačníku v podobě loukot’ového kola, $\mathrm{v}$ jehož středu je z horní strany uchycena vytáčecí deska. 

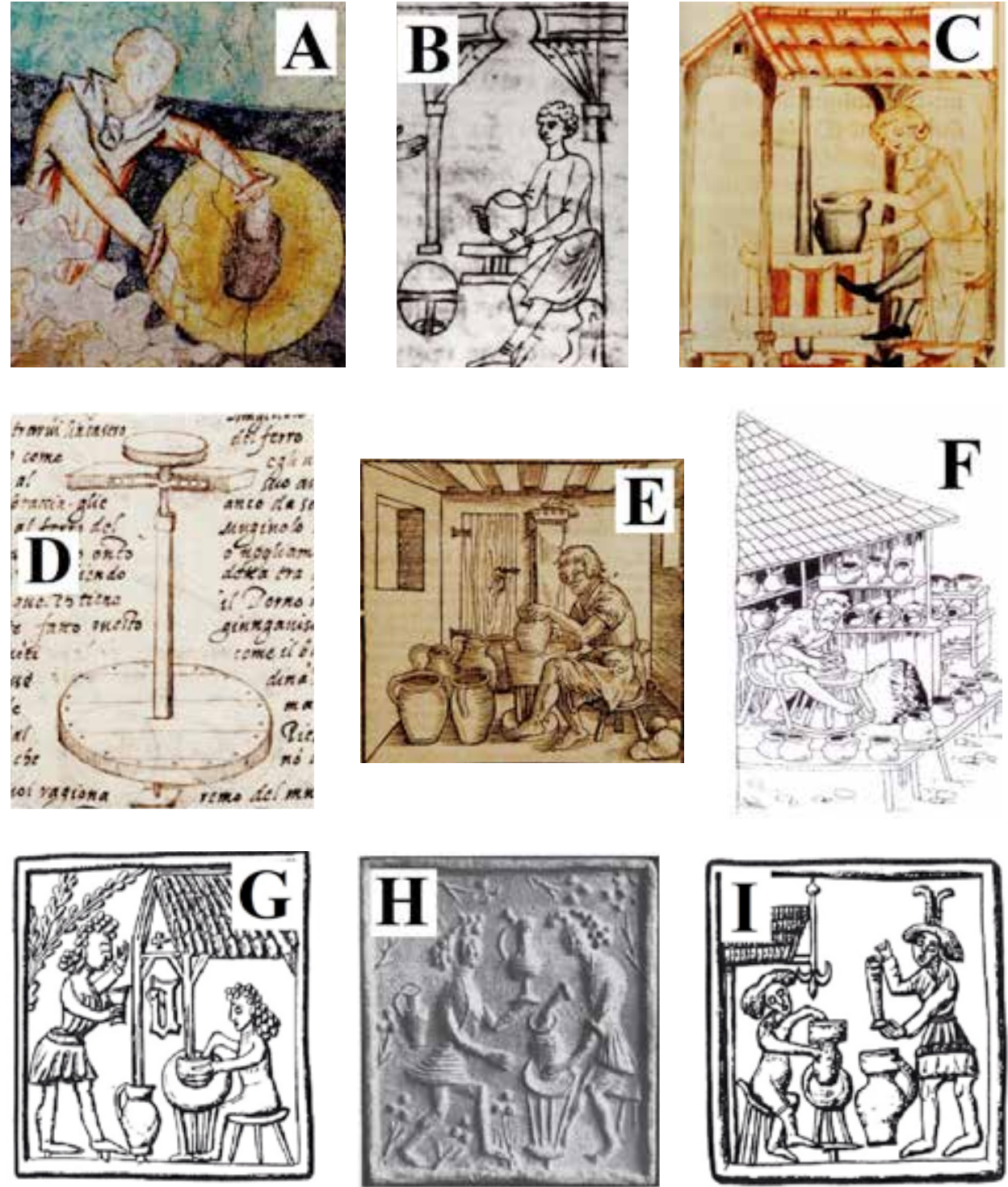

Obr. 1. Vybrané typy pomalu- (A-B) a rychloobrátkových (C-I) kruhů z vrcholného středověku a raného novověku: A Dóm v Gurku, Rakousko, západní empora, 13. století; B - Musée de la Céramique d’Andenne, b. d.; C - Concordantiae Caritatis, Stiftsbibliothek, Cod. 151, Lilienfeld, okolo 1355; D - vyobrazení kopacího kruhu v díle Cipriana Piccolpassa, 1556-1559, fol. 9v; E - hrnčířská dílna na dřevořezbě z 16. století; F - Georgius Agricola, De re Metallica, 1556; G-I hrnčířské kruhy na čelních vyhřívacích stěnách kachlủ z našeho území: G - hrad Landštejn; H - hrad Lichnice; I - hrad Týřov. A-E - podle Kaltenberger 2009, Abb. 97, 98, 108, 104, 118, 310-312, 315; F - podle Zimola 2013, 148; G, I - podle Pavlík-Vitanovský 2004, 262, obr. 779, 781; H - podle Kotík 1954, 57.

Abb. 1. Ausgewählte Typen von langsam (A-B) und schnell drehenden (C-I) Töpferscheiben aus dem Hochmittelalter und der frühen Neuzeit: A - Dom zu Gurk, Österreich, Westempore, 13. Jahrhundert; B - Musée de la Céramique d'Andenne, b. d.; C - Concordantiae Caritatis, Stiftsbibliothek, Cod. 151, Lilienfeld, um 1355; D - Darstellung einer fußbetriebenen Töpferscheibe im Werk von Cipriano Piccolpasso, 1556-1559, fol. 9v; E - Töpferwerkstatt auf einem Holzschnitt aus dem 16. Jahrhundert; F - Georgius Agricola, De re metallica, 1556; G-I - Töpferscheiben auf böhmischen Blattkacheln: G - Burg Landštejn; H - Burg Lichnice; I - Burg Týřov. A-E - nach Kaltenberger 2009, Abb. 97, 98, 108, 104, 118, 310-312, 315; F - nach Zimola 2013, 148; G, I - nach Pavlík-Vitanovský 2004, 262, Abb. 779, 781; H - nach Kotík 1954, 57. 


\section{Loukot'ové kolo a jeho výroba ve středověku a raném novověku}

Než popíšeme historické prameny zobrazující loukot’ové kruhy, je třeba vysvětlit, co je loukot' a jak a kdo takové kolo vyráběl (nebot' šlo o specializovanou a výrobně náročnou záležitost, kterou zvládal jen specializovaný řemeslník). Podíváme-li se do slovníku z dob, kdy toto kolo bylo běžným řemeslným výrobkem, pak například J. Jungmann (1836, 270-271) mj. uvádí: „Laukot'-křiwina lukowá (...) wykrauhlené w spůsob črwrtměsjce dřewa, které drewénými hřebíky dohromady spogené okolek čili okruh kola působj, luk u kola (...). Wưz má kola z pjste [? nelze přečíst] špic 12, laukotj šesti a tolika též šjnů složená [šín = kování kol, pozn. autor] (...).“

Výrobu loukot’ových kol zajištovali koláři (lat. plaustrifices), též koloději či nápravníci (neplést s nápravníky v sociálním smyslu - v tomto významu odvozeno od náprav vozů; tito dále vyráběli kostry do vozů a saní a od konce středověku a raného novověku se jim říkalo též korbáři, štelmářri a podstávkáři), kteří měli být osedlí ve všech větších městech i na venkově. Pro Prahu pak máme doloženy i specialisty kolečníky (lat. rotulifices), kteří zhotovovali trakaře a kolečka (Winter 1906, 452-453).

V Praze do roku 1419 napočítal Z. Winter 43 kolářů, přičemž do konce 15. století se jich deset stalo měšt’any a roku 1524 jich přišlo $\mathrm{k}$ přísaze na radnici dvanáct a jeden nápravník (Winter 1906, 10, 146, 452-453). Od roku 1391 působil na Starém Městě pražském wegenmacher, postupně jich přibývalo a počeštili se na vozáky (currifices). Oproti kolářům hotovili tito rovnou celé vozy, ovšem v pozdějších dobách je takto vyráběli už i koláři. Koláři patřili nejčastěji do spojeného cechu s kováři, ale i s dalšími podobnými řemesly, což máme doloženo například z Jihlavy před rokem 1349 nebo Turnova z roku 1519. V patnáctém století jsou jmenováni tři v Rakovníku, roku 1432 jich bylo v Táboře pět, větší množství v Hoře (Kutné). Čtyři působili taktéž jako konšelé na Malé Straně a dva na Novém Městě v Praze (Winter 1906, 200, 452-453, 657). Kolik mohlo stát loukotové kolo, udává, bohužel jen orientačně, zmínka z roku 1522 ze Stř́ibra, kdy bylo placeno za: „dvě kola, voj a vosy 32 grošü“ (Winter 1906, 850).

V české archeologické odborné literatuře se vozům, a logicky i jejich kolům věnoval nejobsáhleji R. Vermouzek (1983). Ten uvádí, že podoba vozu byla již v průběhu 13. a 14. století ustálena, ovšem nadále se vyvíjela $v$ detailech. Pro naše potřeby si však budeme nadále všímat jen konstrukce kola. To se skládalo ze tří základních částí: hlavy (střed), paprsků neboli špic a loukotí (ráfku). Vzhledem k rozdílné námaze způsobené jak povětrnostními, tak fyzikálními vlivy byly části kola vyráběny z různých druhů dřev (např. bříza a buk, viz Winter 1906, 850). Nejnamáhanější byly hlavy, které bývaly vyrobeny ze středů kmenů stromů. Tyto ovšem vlivem sesychání praskaly. Proto bývaly vyráběny i ze silnějších kmenů, které koláŕ rozštípal na poloviny či čtvrtiny, a hlavy byly následně vysekány sekerou a pořízem (soustruhu se neužívalo, viz obr. 2:A). Toto řešení však také nebylo bezchybné, nebot' i v tomto př́ípadě docházelo k deformaci sesycháním (Vermouzek 1983, 311-312).

Do vývrtů v hlavě, které byly proraženy až ke středové ose, byly usazeny paprsky. Pro malá kola se usazovala jedna loukot' na jeden paprsek, u větších kusů na dva paprsky. Ty byly na kole umístěny nepravidelně, a to co nejblíže spojům jednotlivých loukotí (kvůli lepšímu rozložení váhy na spoje). Do hlavy byly paprsky uloženy volněji a do loukotě, kterou procházely skrz, byly na vnějším okraji zaklínkovány. Pro lepší spoj pak mohlo být vše zalepeno přírodním lepidlem z tvarohu či tvarohu smíchaného s hašeným vápnem v poměru 2: 1 (Vermouzek 1983, 312-313).

Vnější obvod kola tvořily loukotě. Jak bylo výše popsáno, jde o zakřivené části kola tvořící jeho „ráfek“. Vyráběly se opět z kmene stromu rozštípaného na poloviny či čtvrtiny (obr. 2:B). Počet loukotí byl nejčastěji čtyři až deset, dle velikosti kola. Spojeny byly kolíčky nebo klínky na vnější straně spojů. Z fyzikálního hlediska byla pro provoz lepší kola vyšší (ovšem tím pádem více namáhaná a ničená), nebot' se snadněji rozjížděla, a širší, nebot' se tolik nebořila. Velmi důležitým konstrukčním prvkem bylo vyhnutí paprsků vůči hlavě. Mnohé iluminace v rukopisech z vrcholného středověku sice ukazují kola s těmito paprsky zdánlivě usazenými kolmo, ovšem i zde byl výklon minimálně $1-2$ couly $(1 \mathrm{coul}=$ ca $25 \mathrm{~mm})$. Směrem k ranému novověku se tento 
výklon zvyšuje (obr. 2:C). Důvodem bylo lepší rozložení bočního tlaku na kolo (Vermouzek 1983, 312-314).

Pro celkové zpevnění kola se mohlo použít i kování menšími železy či kovovou obručí (šíny). Toto však bylo ve středověku spíše okrajovou záležitostí a pro potřeby tohoto článku nebude problematika dále rozvedena (Vermouzek 1983, 314-315).

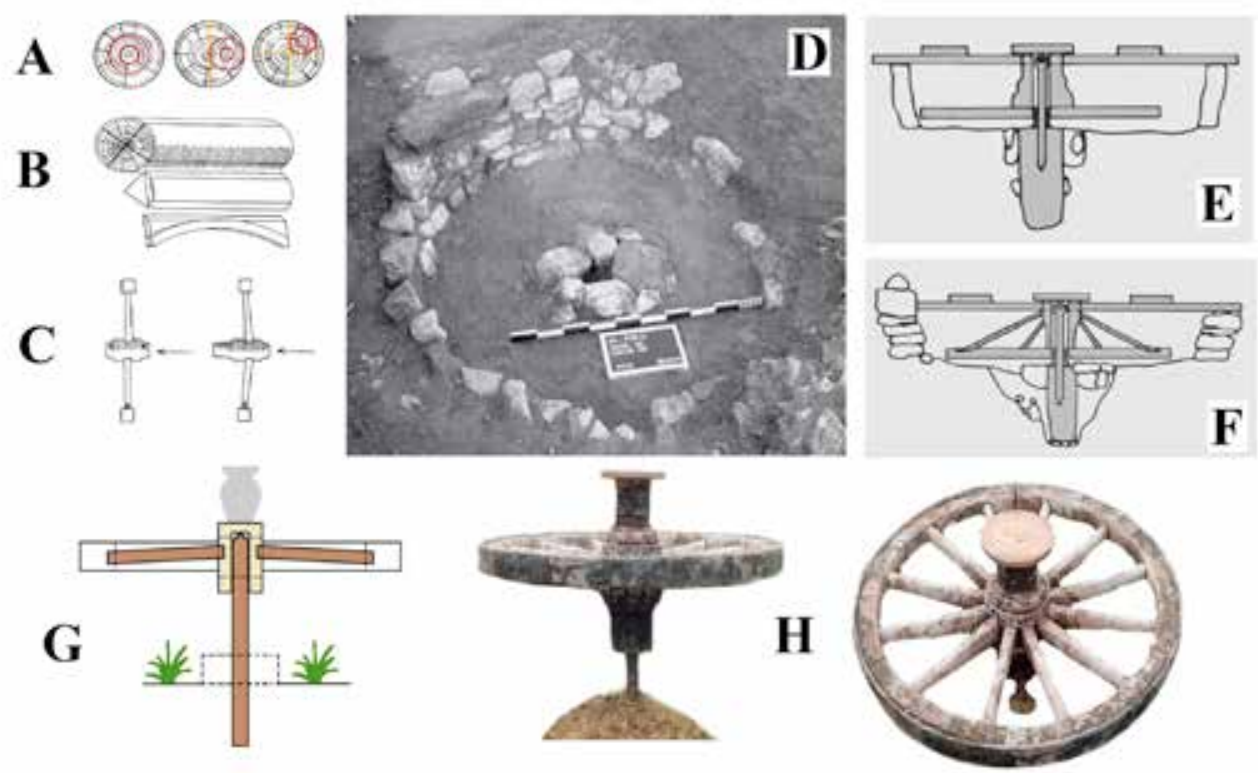

Obr. 2. Výroba loukot’ového kola/kruhu a jeho konstrukce. A - výroba hlavy z kulatiny, její poloviny a čtvrtiny; B - výrobní postup loukotě; C - výklon paprsků kola (bokorys); D-základy raně novověké točířské dílny z Raeren, Belgie; E-F - rekonstrukce kruhu s rámovou konstrukcí dle nálezu z Raeren (LOC.01 a LOC.03); G - konstrukce volně stojícího loukot'ového kruhu; H - experimentálně rekonstruovaný kruh. A-C - podle Vermouzek 1983, 312, obr. 1-2, 314, obr. 4; D-F - podle Laterme 2008, Abb. 3, Abb. 15-16, 159, 166; G-H - kresba a foto P. Macků.

Abb. 2. Herstellung und Bauweise eines Töpferrades/einer Töpferscheibe. A - Herstellung des Kopfstücks aus Rundholz, Hälfte und Viertel davon; B - Arbeitsschritte bei der Herstellung der Radfelge; C - Unwucht der Radspeichen (Seitenriss); D - Fundament einer frühneuzeitlichen Töpferwerkstatt aus Raeren, Belgien; E-F - Rekonstruktion von Töpferrädern nach den Befunden aus Raeren (LOC.01 a LOC.03); G - Bauweise eines frei stehenden Töpferrades; H - experimentell rekonstruiertes Töpferrad. A-C - nach Vermouzek 1983, 312, Abb. 1-2, 314, Abb. 4; D-F - nach Laterme 2008, Abb. 3, Abb. 15-16, 159, 166; G-H - Zeichnungen und Fotos P. Macků.

\section{Loukot'ový kruh v obrazových pramenech 13.-17. století}

V rámci obsáhlé rešerše historických pramenů se podařilo dohledat šestnáct vyobrazení pojednávaného typu hrnčířského kruhu (obr. 3). Deset z nich bylo již dříve publikovaných (v různém zastoupení v Guadagnin 2007, 62, Figure 34; Kaltenberger 2009, 318-321, Abb. 128-136; Laterme 2008, 160-164, Abb. 4-8, 11), ovšem v popisném textu nebyl vždy citován pramen. Nám se podařilo dohledat většinu z nich, včetně názvu historického pramene, jeho uložení, případně prezentaci ve veřejně dostupném online katalogu (tab. 1).

Celkově jde o čtyři obrazy z 13. století (obr. 3:A-D), čtyři ze století následujícího (obr. 3:E-H), pět ze století patnáctého (obr. 3:I-L, N), dva ze šestnáctého (obr. 3:M, P) a jeden ze sedmnáctého (obr. 3:O). Je pravděpodobné, že při budoucí rešerši se podaří dohledat další, především z raně novověké éry. U dohledaných pramenů dominuje jako země původu Francie $(9 \times)$, po jednom zastoupení je původ italský a nizozemský (5× nedohledán). Četnost pramenů sice 
nedovoluje vyvodit širší závěry ohledně teritoriality užívání daného kruhu, ovšem jejich koncentrace v západní Evropě může ledacos naznačovat (i s přihlédnutím k pozdějším novověkým pramenům, viz dále).

Z hlediska konstrukce kruhu můžeme rozlišit tři varianty. Nejjednodušší je loukot'ové kolo usazené na svislou nosnou osu ukotvenou přímo do země (nejnázorněji obr. 3:J, M). Pro lepší vycentrování osy pak mohla být tato ještě vsunuta do „kamenného“ bloku položeného na pochozí terén (obr. 3:I; konstrukce viz obr. 2:G). To, že osa tímto blokem prochází až do lůžka v zemi, a nikoli pouze do něj, ukázal experiment. Základna pro ukotvení osy (v nadzemní verzi) totiž musí být širší než roztáčené kolo, jinak se celý kruh rozvibruje a může se i svalit.

Složitější a zároveň i bezpečnější verzí je ukotvení kruhu v rámové konstrukci ze dřeva (obr. 3:F, G, K, L, O). Chodidla měl totiž hrnčír nad úrovní roztočeného kola a šance na zranění se minimalizovala (viz kapitola o experimentu). Lidská kreativita ovšem přinesla i zjednodušené řešení, kdy hrnčíř zvyšuje úroveň svých nohou oproti kruhu pomocí stoliček, na kterých stojí (obr. 3:I, J). Kromě jednoduché konstrukce máme zachyceny i složitější patrové - na horních policích má hrnčiř odložené čerstvě vytočené kusy či kalník - nádobu na namáčení rukou (obr. 3:F, G). Jinak pro dočasnou deponii nových nádob slouží lavice, stolky, police na zdech či přímo podlaha.

Pozůstatky základen pro rychloobrátkové kruhy s pravděpodobnou rámovou konstrukcí máme doloženy z Raeren v Belgii. Archeologickým výzkumem zde byly zachyceny tři základny zahloubené do země na dvou hrnčířských okrscích z přelomu středověku a raného novověku. Dva, ležící od sebe zhruba $2 \mathrm{~m}$, byly vyzděny z kamene na maltu do kruhového tvaru o velikosti $160-180 \mathrm{~cm}$ a výšky $30-35 \mathrm{~cm}$. Plocha první základny byla vymazána hlínou a nesla pozůstatky stop po kotvení osy kruhu o rozměrech $20-23 \mathrm{~cm}$, s hlubokou sahající $50 \mathrm{~cm}$ pod úroveň kamenného věnce. Doprovodné keramické nálezy z konce 15. a počátku 16. století ji vřazují do první poloviny 16. století (Leterme 2008, 157-159).

Druhá „točírna“, taktéž s kruhovou vyzděnou zídkou po obvodu, měla ve svém středu zahloubenou další jámu (hl. $40 \mathrm{~cm})$ o šíři $42-66 \mathrm{~cm}$ a s částečným obložením kameny. Byla zasypaná šedým jílem. Oproti předcházejícím byla mladší a doprovodný keramický materiál ji vřazuje do poloviny až druhé poloviny 16. století (Leterme 2008, 157-158).

Konečně třetí, poněkud vzdálená točírna objevená při pozdějším výzkumu se nacházela poblíž dalších zděných destrukcí, které však nejdou prokazatelně spojit s hrnčířským okrskem (obr. 2:D, rekonstrukce objektu na obrázku 2:F). Byla taktéž vyzděna do kruhového tvaru o průměru $170 \mathrm{~cm}$. I ona nesla stopy po ukotvení osy rychloobrátkového kruhu. Datování spadá mezi první až třetí třetinu 16. století (Leterme 2008, 158).

Třetím typem, v obrazových pramenech ojedinělým, je loukotové kolo umístěné na stole a roztáčené rukou (obr. 3:P). Zde byla nosná osa zakotvena přímo do desky stolu.

S konstrukcí souvisí i umístění kola vůči hrnčířovu tělu. Nejníže je položené v rámové konstrukci, kdy je výškově pod úrovní řemeslníka. U volně stojící varianty se pohybuje nejčastěji $\mathrm{v}$ úrovni mezi kotníky a koleny, málokdy výše (nutno brát v úvahu i nedokonalost a schematičnost zatím zcela nechápané perspektivy u pramenů 13. století). To je dáno i posezem hrnčíře, který musí mít pro práci s takovýmto kruhem široce roztažené nohy.

Roztáčení kruhu si zajištuje točír sám pomocí tyče. Jedinou výjimkou je vyobrazení z 15. století, na němž ho roztáčí pomocník tyčkou opřenou o svrchní část loukotě a hrnčír se plně věnuje tváření nádoby (obr. 3:J, teoreticky možná spoluúčast je i na obr. 3:E). V některých případech drží řemeslník tyč obouruč a zaklesnutou ji má o špici, případně roh špice a loukoti. Tyto obrazy zachycují práci s rychle roztočeným kruhem. Naopak v situacích, kdy hrnčír potřebuje nižší točivou rychlost (např. čištění kruhu nožem - obr. 3:G), dotváření čistých tvarů či detailů (obr. 3:A-B, D, F), drží tyč jednou rukou a druhou se věnuje nádobě. Zastoupeno je zaklesnutí tyče jako v předchozím prŕípadě, ale i opřením a posunováním o horní hranu loukotě. Toto rozlišení zachycených fází roztáčení kruhu na iluminacích je odvozeno na základě experimentu, kdy se ukázalo, že jednoruční úchop není pro dosažení rychlých obrátek dostatečný. Navíc se při jednoručním úchopu potkává ruka tvárííí nádobu s rukou držící roztáčecí hůl, takže lze tímto 
způsobem roztáčet kruh jen v omezeném rozsahu (zhruba půl až tři čtvrtě otáčky). Roztáčení na pomalé obrátky lze plně nahradit pouhou rukou, které je, alespoň dle experimentu, efektivnější.

Oděvy hrnčírư nevykazují žádná specifika oproti běžně nošeným typům oděvu té které doby. Někteří mají vyhrnuté rukávy u svrchního šatu i košile, někteří pouze u svrchního šatu, někteři si starost se špinavými rukávy nedělají. Několikrát je zastoupena zástěra.
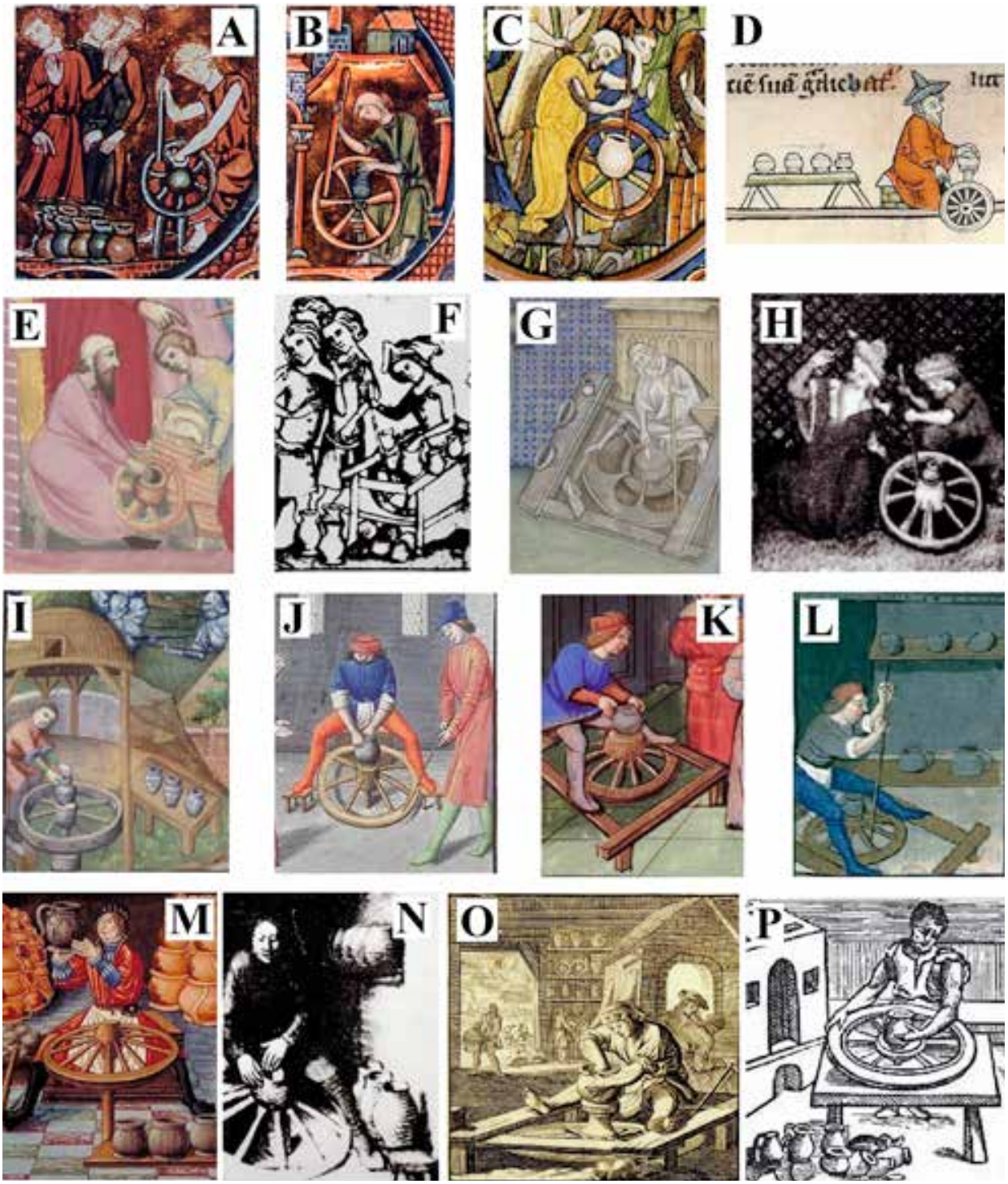

Obr. 3. Vyobrazení loukot'ového kruhu ve stř̌edověku a raném novověku. Popis viz tab. 1. Abb. 3. Darstellungen von Töpferrädern aus dem Mittelalter und der frühen Neuzeit. Beschreibung siehe Tab. 1. 


\section{Loukot'ový kruh v 18.-21. století}

Zajímavým se ukazuje fakt, že pojednávaný typ kruhu se používá v některých zemích dodnes. Díky rozvoji fotografie máme doložené i některé hrnčířské rodiny a dílny z počátku 20. století, především z oblasti Francie (obr. 4:A). Rozsáhlou sbírku pohlednic na svých webových stránkách prezentuje keramik Yvon Le Douget (online: YLD 1 a 2). Tyto fotografie jsou zároveň i sociálním dokumentem, ukazujícím nuzné prostředí hrnčíren, oděvy, vypalovací pece a domy hrnčířù. Keramičtí mistři na kruzích rozdílných provedení vytáčejí klasické zboží, ale i obrovské duté zásobní nádoby. Kruhy jsou vyrobeny minimalisticky ze dřeva a kamenů (podpěry konstrukcí), jak volně stojící, tak v rámových konstrukcích. Všechny varianty si však hrnčír roztáćí sám, bez pomocníka. Bokorys těchto kruhů z doby kolem roku 1850 máme dochován $\mathrm{v}$ díle A. Brongniarta, př́ípadně v jeho přetisku (Kaltenberg 2009, 321, Abb. 137a-b). Z přelomu 19. a 20. století je dochovaný př́mo i jeden loukotový kruh. Je uložen ve sbírkách Töpfereimuseum Langerwehe v Německu (publikovaný v Kaltenberg 2009, 322, Abb. 140-141).

Na rozšíření hrnčířského kruhu ve formě roztočeného kola v Asii upozornil P. Rada (1956, 99-103). Indové ho používají dodnes v různých modifikacích, jak lze vidět na četných videozáznamech webového kanálu YouTube (např. pod heslem „Indian pottery it's amazing“, odkaz platný k 14. 7. 2017). Tento hrnčír, stejně jak popisuje P. Rada, pracuje na kruhu, jehož loukotě jsou oplácané silnou vrstvou hlíny, která mu zaručuje rotaci po několik minut (dle P. Rady ca 5-7). Takto upravené kolo je usazeno na železný či dřevěný hrot pevně ukotvený v zemi. Hrnčíř pracuje ve stoje, respektive $\mathrm{v}$ předklonu. Po ruce má pouze kalník, ze kterého neustále namáčí vytáčenou nádobu a jednoduché nástroje (zde obr. 4:B, podle Rada 1956, 105, obr. 102). Postup je klasický pro práci s rychloobrátkovými kruhy, kdy z masy keramického těsta je vytažena prvně kachlice, která se teprve poté tvaruje dle požadavku řemeslníka. Výrobní proces několika druhů keramiky v Indii, zahrnující i loukot’ová kola, popisuje A. Roux (2003, 769-770).

P. Rada dále popisuje kruh z Japonska a Č́ny, u kterého hrnčíř sedí a roztáčí ho tyčkou vsazovanou do otvoru na obvodu desky. Kruh je usazen přes porcelánové ložisko na dřevěnou osu (zde obr. 4:C; Rada 1956, 105, obr. 101).

Konstrukce loukot’ového kruhu je tedy nadčasová, což potvrzuje staletá praxe jejího používání až do dnešních dní.
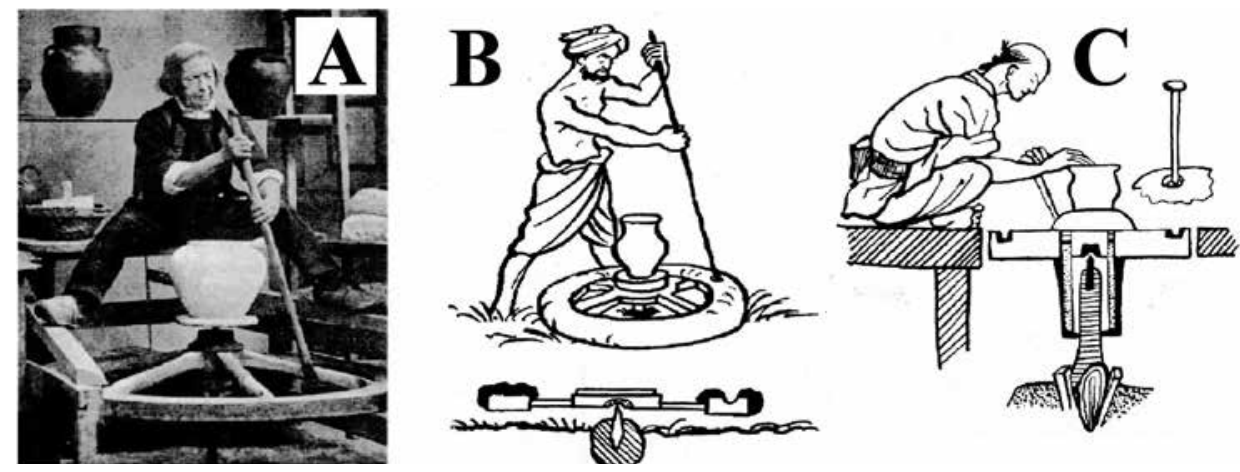

Obr. 4. Etnografická zobrazení kruhů a jejich variabilita ve 20. století. A - bretaňský hrnčír okolo roku 1910; B - indický hrnčíŕ; C - kruh užívaný v Č́ně a Japonsku. A - podle Kaltenberger 2009, 322, Abb. 139; B-C - podle Rada 1956, 105, obr. 100-102.

Abb. 4. Ethnographische Darstellungen von Töpferrädern und seine Ausprägungen im 20. Jahrhundert. A - bretonischer Töpfer um das Jahr 1910; B - indischer Töpfer; C - in China und Japan verwendetes Töpferrad. A - nach Kaltenberger 2009, 322, Abb. 139; B-C - nach Rada 1956, 105, Abb. 100-102. 


\begin{tabular}{|c|c|c|c|}
\hline Číslo & Typ & Datace a původ & Pramen \\
\hline A & Volně stojící & $\begin{array}{l}\text { 1201- } 1300 \\
\text { (1. polovina } 13 \text {. století) }\end{array}$ & $\begin{array}{l}\text { Emblèmes bibliques, volume comprenant la fin de Job, le Psautier, } \\
\text { les livres de Salomon et les Prophètes., Ms. Lat. } 11560 \text {, fol. 174r }\end{array}$ \\
\hline B & Volně stojící & $\begin{array}{l}1201-1300 \\
\text { (1. polovina } 13 \text {. století) }\end{array}$ & $\begin{array}{l}\text { Emblèmes bibliques, volume comprenant la fin de Job, le Psautier, } \\
\text { les livres de Salomon et les Prophètes, Ms. Lat. } 11560 \text {, fol. 141v }\end{array}$ \\
\hline $\mathrm{C}$ & Volně stojící & 1225-1249, Paříž & Bible Moralisée, Codex Vindobonensis 2554, fol. 16r \\
\hline $\mathrm{D}$ & Volně stojící & $\begin{array}{l}\text { 4. čtvrtina 13. století, } \\
\text { severovýchodní Francie }\end{array}$ & Bible, MS M.969 \\
\hline $\mathrm{E}$ & Volně stojící & 1340-1350, Francie & Bible historiée toute figurée, Français 9561 \\
\hline $\mathrm{F}$ & Rámová konstrukce & 1345-1355, Francie & Biblé moralisée, Français 167, fol. 200r \\
\hline G & Rámová konstrukce & 1375-1377, Francie & $\begin{array}{l}\text { Saint Augustin, De Civitate Dei, traduit en français par Raoul de } \\
\text { Presles (Livre I-X), Français 22912, fol. 227v }\end{array}$ \\
\hline $\mathrm{H}$ & Volně stojící & 14. století & $?$ \\
\hline I & Rámová konstrukce & 15. století, Francie & $\begin{array}{c}\text { Des Cas des nobles hommes et femmes de Jehan Boccace, traduction } \\
\text { de laurent du premierfait, Français } 235\end{array}$ \\
\hline $\mathrm{J}$ & Volně stojící & $1478-1480$ & The Hague, MMW, 10 A 11, fol. 232v \\
\hline $\mathrm{K}$ & Rámová konstrukce & 1498, Francie (Pařiž) & Bible historiale, Lyon, BM, inc. 0058, fol. 29 \\
\hline $\mathrm{L}$ & Rámová konstrukce & 1498, Francie (Paříž) & Bible historiale, Lyon, BM, inc. 0058, fol. 92 \\
\hline M & Volně stojící & 1519-1528, Francie (Rouen) & $\begin{array}{l}\text { Chants royaux sur la Conception, couronnés au puy de Rouen de } \\
\qquad 1519 \text { à } 1528 \text {, Français } 1537\end{array}$ \\
\hline $\mathrm{N}$ & Volně stojící & 15. století & z díla Jeana Fouqueta \\
\hline $\mathrm{O}$ & Rámová konstrukce & 1694(8), Nizozemí & Livre des métiers, mědiryt od Jana Luykena \\
\hline$P$ & $\begin{array}{l}\text { Volně stojící / ruční } \\
\text { pohon }\end{array}$ & 1540, Itálie (Benátky) & Vannoccio Biringucci: De la pirotechnia. Libri X., BH FG 726 \\
\hline
\end{tabular}

Tab. 1. Seznam obrazových pramenů z 13.-17. století vyobrazujíćch loukot’ové kruhy, popis obr. 3. Internetové odkazy platné k 24. 8. 2017. 


\begin{tabular}{|c|c|c|}
\hline Uložení & Literatura & Poznámka \\
\hline $\begin{array}{l}\text { Bibliothèque nationale de France, Départe- } \\
\text { ment des Manuscripts }\end{array}$ & $\begin{array}{l}\text { Kaltenberger 2009, 318, Abb. } 128 \mathrm{a}-\mathrm{b} ; \\
\text { Leterme 2008, Abb. } 5,160\end{array}$ & $\begin{array}{c}\text { http://gallica.bnf.fr/ark:/12148/btv1b10538038j/ } \\
\text { f351.item.r }=11560\end{array}$ \\
\hline $\begin{array}{l}\text { Bibliothèque nationale de France, Départe- } \\
\text { ment des Manuscripts }\end{array}$ & $\begin{array}{c}\text { Guadaginin } 2007 \text {, Figure } 34,62 \text {; Kalten- } \\
\text { berger } 2009,318 \text {, Abb. } 129 \mathrm{a}-\mathrm{b} \text {; Leterme } \\
2008 \text {, Abb. } 6,161\end{array}$ & $\begin{array}{c}\text { http://gallica.bnf.fr/ark:/12148/btvlb10538038j/ } \\
\text { f286.item.r }=11560\end{array}$ \\
\hline $\begin{array}{l}\text { Österreichische Nationalbibliothek, De- } \\
\text { partment of Manuscripts and Rare Books }\end{array}$ & & http://data.onb.ac.at/rec/AL00152849 \\
\hline $\begin{array}{l}\text { Pierpont Morgan Library, Dept. of Medie- } \\
\text { val and Renaissance Manuscripts }\end{array}$ & & $\begin{array}{l}\text { http://ica.themorgan.org/manuscript/ } \\
\text { page/32/145388 }\end{array}$ \\
\hline $\begin{array}{l}\text { Bibliothèque nationale de France, Départe- } \\
\text { ment des Manuscripts }\end{array}$ & Kaltenberger 2009, 319, Abb. 130a-b & $\begin{array}{c}\text { http://gallica.bnf.fr/ark:/12148/btv1b7200010r/ } \\
\text { f111.item.r=Ms\%20Fran } \% \text { C3\%A7ais\%209561. } \\
\text { zoom }\end{array}$ \\
\hline $\begin{array}{l}\text { Bibliothèque nationale de France, Départe- } \\
\text { ment des Manuscrits }\end{array}$ & $\begin{array}{l}\text { Kaltenberger 2009, 319, Abb. 132a-b; } \\
\text { Leterme } 2008, \text { Abb. 7, } 161\end{array}$ & $\begin{array}{c}\text { http://gallica.bnf.fr/ark:/12148/btv1b8447300c/ } \\
\text { f407.item.r=167\# }\end{array}$ \\
\hline $\begin{array}{l}\text { Bibliothèque nationale de France, Départe- } \\
\text { ment des Manuscrits }\end{array}$ & $\begin{array}{l}\text { Kaltenberger } 2009,320, \text { Abb. } 135 \mathrm{a}-\mathrm{b} \\
\text { Leterme } 2008, \mathrm{Abb} .8,162\end{array}$ & $\begin{array}{l}\text { http://gallica.bnf.fr/ark:/12148/btv1b8447874d/ } \\
\text { f458.image }\end{array}$ \\
\hline$?$ & Kaltenberger 2009, 319, Abb. 131a-b & $\begin{array}{l}\text { Obrázek z fondu Musée de la Céramique } \\
\text { d'Andenne }\end{array}$ \\
\hline $\begin{array}{l}\text { Bibliothèque nationale de France, Départe- } \\
\text { ment des manuscrits }\end{array}$ & & $\begin{array}{l}\text { http://gallica.bnf.fr/ark:/12148/btvlb9007632h/ } \\
\text { f332.item.r=Des\%20Cas\%20des\%20nobles\%20 } \\
\text { hommes\%20et\%20femmes\%20235.zoom }\end{array}$ \\
\hline $\begin{array}{c}\text { Koninklijke Bibliotheek - National Library } \\
\text { of the Netherlands }\end{array}$ & & $\begin{array}{l}\text { http://manuscripts.kb.nl/show/ } \\
\text { images_text } / 10+\mathrm{A}+11 / \text { page } / 47\end{array}$ \\
\hline ? & & $\begin{array}{l}\text { http://initiale.irht.cnrs.fr/decors/decors. } \\
\text { php?id=65411\&indexCourant }=30 \& \text { \&loc_recher- } \\
\text { che_decor=none\&bloc_resultats_decor=no- } \\
\text { ne\&resetForm=1\&page=1\&ouvrageId }=2226\end{array}$ \\
\hline ? & & $\begin{array}{l}\text { http://initiale.irht.cnrs.fr/decors/decors. } \\
\text { php?id=65631\&indexCourant }=-1 \& \text { bloc_recher- } \\
\text { che_decor=none\&bloc_resultats_decor=bloc- } \\
\text { k\&resetForm }=1 \& \text { page }=1 \& \text { ouvrageId }=2226\end{array}$ \\
\hline $\begin{array}{l}\text { Bibliothèque nationale de France, Départe- } \\
\text { ment des manuscrits }\end{array}$ & Kaltenberger 2009,320 , Abb. $134 a-b$ & $\begin{array}{c}\text { http://gallica.bnf.fr/ark:/12148/btvlb8539706t/ } \\
\text { f205.item.zoom }\end{array}$ \\
\hline$?$ & Kaltenberger 2009, 320, Abb. 133a-b & $\begin{array}{l}\text { Obrázek z fondu Musée de la Céramique } \\
\text { d'Andenne }\end{array}$ \\
\hline University of Toronto Libraries & $\begin{array}{l}\text { Kaltenberger 2009, 321, Abb. } 136 \text {; } \\
\text { Leterme 2008, Abb. 4, } 160\end{array}$ & $\begin{array}{l}\text { http://utpictura18.univ-montp3.fr/Generateur- } \\
\text { Notice.php?numnotice=A8717 }\end{array}$ \\
\hline $\begin{array}{l}\text { Biblioteca Complutense Madrid, Bca. } \\
\text { Histórica-Fco. Guerra }\end{array}$ & $\begin{array}{c}\text { Leterme 2008, Abb. 11, 164; freeware: } \\
\text { https://books.google.cz/books/ucm?vi- } \\
\text { d=UCM5322486027\&printsec=frontco- } \\
\text { ver\&redir_esc=y\#v=onepage\&q\&f=- } \\
\text { false }\end{array}$ & 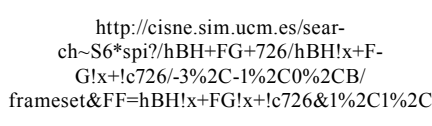 \\
\hline
\end{tabular}

Tab. 1. Verzeichnis der Bildquellen aus dem 13.-17. Jahrhundert mit Darstellung von Töpferrädern, Beschreibung von Abb. 3. Internetlinks aufgerufen am 24. 8. 2017. 


\section{Experimentální rekonstrukce loukot’ového kruhu a práce s ním}

Experimentem měla být zodpovězena řada otázek, mezi něž patří především technické a konstrukční řešení kruhu, práce s ním a jeho porovnání s rychloobrátkovými kruhy jiných typů.

Prioritou bylo ověření práce s kruhem, proto byla vytvořena jen volná replika. Jako základ posloužilo loukotové kolo pravděpodobně z 19 . století o průměru $82 \mathrm{~cm}$ a šíři loukotí $5,5 \mathrm{~cm}$ (dar M. Hanzlíka, kastelána hradu Lipnice, za což mu touto formou děkuji). Tvořené je okovaným středem, šesti loukotěmi a dvanácti špicemi. Po obvodu loukotí je nasazena železná obruč a stejně zpevněné jsou i části hlavy kola (vnitřní otvor pro nasazení na oj i jeho vnější obvod při okrajích, viz obr. 2:H, vlevo). Ačkoli z obrazových pramenů nemáme pro kování kol kruhů doklad, byla obruč na kole ponechána $\mathrm{z}$ důvodu zvýšení setrvačnosti otáček vlastní vahou. Kolo bylo poškozené dřevokazným hmyzem a hmota jedné loukotě byla částečně odhnilá, tudíž byla tato částečně vyprotézována klínky mezi kolem a obručí.

První prací bylo fungicidní ošetření a následně i povrchové ošetření zalakováním dřevěných částí. Pro úpravu kola na kruh byly nutné úpravy. Vzhledem k tomu, že provrt středem hlavy šel skrz celou šířku, byla na jednu boční stranu navařena železná destička, která slouží jako opěrka pro točířskou osu. Na stejné straně byla na vnější železný okraj navařena druhá kruhová destička, sloužící jako podložka pod točířskou desku. Ta byla vytvořena ze dřeva a uchycena čtyřmi dubovými kolíky ke spodní podložce, do které jsou vyvrtány čtyři otvory pro jejich usazení (obr. 2:H, vpravo). Kolo se tak od originálů zachycených písemnými prameny liší, nebot' špice ve vodorovné poloze od hlavy $\mathrm{k}$ loukoti stoupají místo toho, aby klesaly (srovnej obr. 2:H a např. 3:K, L, N). Tuto úpravu si vyžádala vnitřní profilace provrtu hlavy, která je kónická. Z logiky je tak lepší kolo nasadit na rotační osu v nejužším místě a osu zhotovit tak, aby se postupně rozšiřovala a aby pokud možno co nejlépe kopírovala vnitřní rozměr provrtu. Kruh sice lze roztočit i bez této úpravy, ovšem volný prostor mezi osou a hlavou kola po kulminaci otáček vytváří vibraci, která nejenže práci velmi ztěžuje, ale zároveň jí i brzdí (optimální „těsné“ ř̌ešení konstrukce ukazuje obr. 2:G). Pro funkci nosné rotační osy byla vybrána železná trubka (kvůli váze kola). Toto řešení nebylo zcela vhodné, protože plocha konce trubky vytvářela velkou třecí plochu vůči kolu a silně brzdila jeho pohyb. Zlepšilo se to po namazání ložiska - styčných ploch - vazelínou, ale kolo se točilo stále málo. Proto byl na konec trubky nasazen zašpičatělý kolík z tvrdého dřeva. Po opětovném promazání vazelínou se rotace kola po roztočení výrazně prodloužila.

Prvním závěrem, ovšem zcela očekávaným, tak bylo zjištění, že ložisko, tedy samotné kolo a rotační osa se musí dotýkat co nejmenší plochou, optimálně potřenou kluzkou hmotou. Pro období středověku i novověku se nabízí použití tuku (sádlo) či oleje (vyráběli ho olejníci či olejovníci - oleatores, viz Winter 1906, 131, 427-428). Nejpravděpodobnější je, vzhledem k používání modifikovaného kola, užití kolomazi - ve středověku a raném novověku všudypřítomné. Kolomaznictví (smolařství a dehtářství) máme ze střední Evropy i u nás doloženo od raného středověku až do 20. století (více v Janotka-Linhart 1987, 15-17; Janoušek-Čihák 1987, 250-255; Šaurová 1979, 33-35, 38; Woitsch 2012, 83-88, zde další literatura).

Budování základny pro ukotvení točné osy se opíralo především o vlastní předpoklady a předchozí zkušenost se zakládáním svislých konstrukcí do kůlových jam. Dle zkoumaných archeologických hrnčířských objektů v belgickém Raeren byla pro ukotvení rotační osy do země vykopána čtvercová jáma o rozměrech stran ca $25 \mathrm{~cm}$ a hloubce $60 \mathrm{~cm}$ (srovnej s Leterme 2008). $\mathrm{Na}$ dno byl vložen plochý kámen, aby se osa nebořila a celá jáma byla vyskládána kameny různých velikostí, které byly prosypávány štěrkem a hlínou. Bylo dbáno na maximálně svislou polohu osy - pomocí elektronické vodováhy se ji podařilo vycentrovat na odchylku $\mathrm{x}=0,1^{\circ}$ a y $=0,4^{\circ}$, tedy výklonu do půl stupně. Nadzemní část nad zásypem pak byla navršena vykopanou hlínou vysvahovanou od osy (její nadzemní část vystupuje ca o $40 \mathrm{~cm}$ nad terén). Při roztočení kruhu měla osa tendenci lehce kmitat s tím, jak si základy „sedaly“. Malé prokmity vedly při pozdější práci někdy k pokažení vytáčené nádoby tím, že se na jedné straně vytvořila 
nerovnost, která se s dalšími rotacemi spíše zvýraznila než potlačila, a zpočátku to vedlo ke zmetkovitosti. Tato situace by však při dobře vycentrované ose neměla nastávat. Používáním kruhu si celá konstrukce postupně „sedla“ a kmitavost se snížila na únosnou mez. Vhodnější by nejspíše byl základ vyzděný na maltu, se kterým by tato starost odpadla.

Jakmile začala konstrukce kruhu funkčně vyhovovat, přešlo se k druhé části experimentu, tj. ověřování obsluhy kruhu a práce s ním. Nezvyklý postoj a posez při práci, zobrazený v ikonografii, v počátku doprovázela bolest spodní části zad, která se však časem vytratila. Důležitějším poznatkem, odzkoušeným na vlastním těle je však nebezpečnost ve fázi vytáčení, kdy musí být hrnčíř pozorný především při roztáčení kola. Ačkoli některé obrazové prameny i videa současných hrnčířů ukazují roztáčení kruhu koncem tyče opřené o vrchní stranu loukotě, ukázalo se efektivnější její zaklesnutí mezi spoj paprsku a loukotě. V tom tkví i zmiňovaná nebezpečnost, nebot' roztáčením tyč postupně sklouzává dolů v šikmém úhlu. Pokud stojí hrnčiř při okraji kola, tyč se při plných obrátkách může zarazit o nohu. Tím může dojít i k destrukci špic nebo dokonce zlomenině nohy (autor tohoto prŕspěvku naštěstí tento neplánovaný experiment přežil jen s pohmožděninou). $\mathrm{Z}$ tohoto důvodu (a $\mathrm{z}$ důvodu pohodlnosti posezu) předpokládám vznik a používání rámových konstrukcí některými hrnčíři v minulosti, nebot' zde má řemeslník nohy nad nebezpečnou úrovní. Stejný problém může nastat i při vyklouznutí roztáčecí tyče z rukou. Při roztáčení je tedy vhodné věnovat této činnosti adekvátní pozornost.

Třetí část experimentu měla za cíl ověřit výrobu nádob z různých keramických hmot a porovnat loukotový kruh s jinými typy. Nutné je však na tomto místě zdůraznit, že vlastní zkušenost s vytáčením nádob zdaleka neodpovídá vyučenému hrnčíři dnes ani v minulosti, a některé vývody tak mohou být subjektivní. Zpočátku byly vytáčeny nejjednodušší tvary, tedy misky a ploché i zvonovité poklice, následně i poháry a menší hrnce.

Ukázalo se, že většina prací již odpovídá vytáčení keramiky na jakémkoli jiném rychloobrátkovém kruhu. K zásadním rozdílům patři především samotné roztáčení kruhu, kdy oproti kopacím kruhům je zapotřebí roztáčet kruh ručně pomocí tyče. Záleží pak na kvalitě provedení ložiska kruhu, jak dlouho se bude točit. Při experimentu se volně rotující kruh točil po maximálním roztočení až 1,5 minuty, přičemž při vytáčení nádob se tento čas krátil na zhruba 20-40 vteřin. Čím hruběji ostřené bylo keramické těsto, tím více se otáčky zbrždovaly. Tento údaj je ovšem pouze doplňkový, protože časy rotace se mohou měnit kruh od kruhu v závislosti na kvalitě provedení ložiska a celkové konstrukce kruhu.

Po nahození adekvátního množství keramického těsta na točířskou desku lze tvářet nádobu rovnou (při malém množství hlíny), nebo přes mezistupeň ve formě vytažené kachlice (jak popisuje např. Rada 1956, 103-108). V každém př́ípadě je nutné hlínu vycentrovat tlakem za stálého namáčení rukou v kalníku. Centrování se provádí snáze při nižších otáčkách, kdy kruh stačí roztočit rukou. Po hrubém srovnání se mohou otáčky zvýšit na maximum a těsto si finálně předpřipravit či přímo tvářet nádoby rovnou.

Pro část experimentu s výrobou nádob posloužilo několik typů keramických hlín, získaných $\mathrm{z}$ dostupných a $\mathrm{v}$ minulosti již navštěvovaných hliníků. Nejprve byla použita hlína připravená podomácku, nakopaná z jihočeských diatomitových jílů (stejná, jaká byla používána dříve pro experimenty s obtáčenou keramikou, viz Macků 2016). K jejímu ostření docházelo metodou „od oka“, tedy nebyly váženy jednotlivé příměsi (nebylo to předmětem experimentu). Ačkoli bylo keramické těsto vizuálně podobné stř̌edověkým originálům, pracovalo se s ním velmi špatně. Přidané ostřivo v hlíně, tvořené drobným křemičitým pískem i menšími kaménky, bylo při vysokých otáčkách pro ruce nepříjemné (princip hrubého smirkového papíru). Zásadnější ale bylo poškozování stěn nádob hrubším ostřivem (kaménky) při vytáčení. Proto nebyla tato hlína nadále v experimentu využita.

Lépe dopadla sprašová hlína z lokality Dolní Bukovsko, poloha K Mikolovům (jižní Čechy), kde probíhá komerční těžba suroviny pro výrobu cihel. Jako vzorek byla v lomu odebrána hlína ze svrchní vrstvy v odtěžené ploše a z jejího profilu. Hlína byla zbavena větších kaménků a organických příměsí (kořínky), smíchána s vodou a přes zimu uložena v uzavřené nádobě, aby se odležela a přemrzla. Na jaře byla znovu zhomogenizována a ještě několik měsíců ponechána 
k odležení. Teprve po třetím zvlhčení a prohnětení byla použita pro experiment. Ačkoli se s ní pracovalo lépe než s předchozím keramickým těstem, nastal opět „efekt smirkového papíru“ kvůli infiltrovanému křemičitému písku (jak bylo psáno výše, šlo o svrchní a splachovou vrstvu hliníku). Nejnepř́ijemnější to bylo především v počátku točení (vytahování kachlice), když je potřeba na těsto při formování více tlačit prsty. Pro další sezonu experimentování je však již naskladněno větší množství pečlivě upravené jemné hlíny.

Keramická těsta s vysokým obsahem aditiv, vhodná pro starší techniky tváření nádob (obtáčení), se tedy naprosto nehodí pro tváření nádob při vysokých rychlostech, jak se běžně uvádí $\mathrm{v}$ tematické literatuře. Kromě zvýšené zmetkovitosti docházelo i k většímu brzdění rotace a pro vytočení každé nádoby musel být kruh roztáčen několikrát, což by se pro hrnčíře v souhrnu jevilo jako neekonomické řešení. U „kopacího“ kruhu by tento problém nenastal, nebot' hrnčíř může vysokou rotaci udržovat po celý čas.

Jako nejvhodnější, zcela očekávatelně, se ukázala komerčně prodávaná točirrská hlína bez makroskopicky viditelných příměsí, která je dobře tvárná a snadno se s ní pracuje. Pro tváření složitějších či vyšších nádob je však nutná předchozí kruhařská praxe. Vzhledem k osobním požadavkům, aby vytvářené nádoby byly vzhledově nerozeznatelné od originálů nejen morfologií, ale i složením keramického těsta, nebylo této hlíny nadále pro experiment využíváno. $\mathrm{V}$ budoucích experimentech bude nutno odzkoušet adekvátní poměr přísad vůči těstu získaných z přírodních hliníků, aby výsledná nádoba měla strukturu středověkých originálů, ovšem zároveň byla i výrobně přijatelná.

Vedle vytáčení byly na loukotovém kruhu samozřejmě prováděny experimenty i s možnostmi obtáčení nádob (tzv. válečková metoda) a s kombinací obou technik. Točířská deska byla posypávána na středu drobným křemičitým pískem, na kterém se mohla nádoba tvořit od „,̌neka“ stočeného z válečku a po okraji „přimáznutého“ prsty k desce. Jiným, rychlejším a efektivnějším způsobem je opatrné vytočení dna a spodní části nádoby, na kterou se teprve lepí další řady válečků. Další postup při tvorbě nádoby je pak stejný jako u zcela obtáčené nádoby (viz Macků 2016, 83-85). Loukot’ový kruh je pro tuto metodu výroby pohodlnější, nebot' se dá roztáčet rukou a dá se dobře regulovat rychlost otáček oproti obyčejné otočné desce pomalu rotujících kruhů. Zásadní rozdíl je pak v zahlazování válečků a úpravě vnitřních i vnějších stěn, kdy se kruh více roztočí a finální práce na nádobě probíhají rychleji a efektivněji. Tímto způsobem tak lze vytvořit nádobu zcela obtáčenou či s různým poměrem vytáčených částí.

\section{Závěr}

V obrazových pramenech se překvapivě často setkáváme s tzv. kruhem loukot'ového typu, a to v dlouhém časovém rozpětí 13.-20. století, potažmo až 21. století v neevropských částech světa (Indie, Japonsko). Nejvíce ikonografických zdrojů pochází z Francie, odkud máme doklady užívání tohoto kruhu téměř z celého výše psaného časového rozsahu. $Z$ našeho území podobné doklady o loukotovém typu hrnčířského kruhu postrádáme. Archeologicky byly pozůstatky základen těchto kruhů zkoumány v belgickém Raeren.

Ikonograficky máme doloženy tři typy loukot'ových kruhů: 1) volně stojící ukotvené přímo do země, 2) v rámové konstrukci (pravděpodobně z důvodu bezpečnosti obsluhy a pohodlnějšího posezu) a 3) kruh usazený př́mo do desky stolu.

Pro představu o funkčnosti byla vytvořena volná replika volně stojícího hrnčířského kruhu ukotvená do vykopané jámy vyložené kamenným základem. Experiment především poukázal na nutnost kvalitního ložiska, které zásadně ovlivňuje veškerou práci s tímto typem kruhu. $\mathrm{V}$ budoucnu bude potřeba vyrobit takovýchto kruhů více a cíle experimentu zaměřit právě na možnosti ložisek, které se mohly používat v průběhu středověku a novověku, včetně studia dobové technické literatury (např. i přímo nesouvisející - De re metallica libri XII od G. Agricoly), a samozřejmě pátrat i po další původní ikonografii. $Z$ hlediska výroby lze na tomto kruhu tvářet nádoby obtáčením a vytáčením, přičemž jde o plnohodnotnou variantu tváření nádob na 
rychloobrátkovém i ručním kruhu. Problematice loukotového kruhu bude potřeba v budoucnu věnovat ještě další prostor.

Za konzultace a poskytnutou literaturu k tématu děkuji Mgr. Kateřině Těsnohlídkové, Mgr. Michalu Hlavicovi a Michalu Kaclovi.

\section{Literatura}

BERGMANN, R., 1993: Mittelalterliche und neuzeitliche Töpferei in Dortmund-Groppenbruch. Vorbericht, Ausgrabungen und Funde in Westfalen-Lippe 8B, 31-39.

GUADAGNIN, R., 2007: Fosses - Vallée de l'Ysieux. Mille ans de production céramique en Île-de-France. Volume 2. Catalogue typo-chronologique des productions. Crahm - Caen.

HLAVICA, M.-NOSEK, V.-VALÁŠKOVÁ, L.-PETŘÍK, J., 2016: Technické značky jako opomíjený archeologický pramen? Fotogrammetrická analýza den nádob z velkomoravských hrnčiřských dílen ze Starého Města (okr. Uherské Hradiště), polohy „U Víta“, AR LXVIII, 381-412.

CHAVARRIA, J., 1996: Velká kniha keramiky. Prủvodce historií, materiály, vybavením a technikami ručního vytváření, vytáčení, výroby forem, vypalování výrobků v pecích a glazování hrnčířských výrobků a jejich keramických předmětů. Praha.

JANOTKA, M.-LINHART, K., 1987: Řemesla našich předků. Praha.

JANOUŠEK, V.-ČIHÁK, J., 1987: Laboratorní testování procesů v kolomazných pecích v souvislosti s úpravami pece u Plzně - Bolevce. In: Zkoumání výrobních objektů a technologií archeologickými metodami 4, 246-271. Brno.

JOSEF, J., 1994: Technologie výroby keramiky. Učební texty pomaturitního studia Národního muzea. Praha.

JUNGMANN, J., 1836: Slownjk česko-německý, djl II., K-O. Praha.

KALTENBERGER, A., 2009: Keramik des Mittelalters und der Neuzeit in Oberösterreich. Band 1, 2. Linz.

KARA, M.-WRESCIŃSKI, J., 1996: Przyczynek do studiów nad wczesnośredniowiecznymi narzędziami garncarskimi z terenu Polski. In: Słowiańszczyzna w Europie średniowiecznej 2 (Kurnatowska, Z., ed.), 155-163. Wrocław.

KOTÍK, J., 1954: Tradice a kultura československé výroby. Praha.

LETERME, C., 2008: Töpferräder und Töpferscheiben: archäologische Befunde und zeitgenössische Abbildungen. In: Soester Beiträge zur Archäologie 9. Archäologie und mittelalterliches Handwerk - Eine Standortbestimmung. Beiträge des 10. Kolloquiums des Arbeitskreises zur archäologischen Erforschung des mittelalterlichen Handwerks, 157-168. Soest.

MACKŮ, P., 2016: Experimentální výroba a užívané obtáčené keramiky. In: Workshopy ke středověké a novověké keramice. Panská Lhota 2015 (Měřínský, Z.-Klápště, J., edd.), 82-89. Brno.

MARTIN, M.-RENUCCI, F., 2016: Guédelon: a castle in the making. Rennes.

NEKUDA, V.-REICHERTOVÁ, K., 1968: Středověká keramika v Čechách a na Moravě. Brno.

ORTON, C.-TYERS, P.-VINCE, A., 1993: Pottery in Archeology. Cambridge.

PAVLÍK, Č.-VITANOVSKÝ, M., 2004: Encyklopedie kachlů v Čechách, na Moravě a ve Slezsku. Ikonografický atlas reliéfů na kachlích gotiky a renesance. Praha.

RADA, P., 1956: Kniha o technikách keramiky. Praha.

ROUX, V., 2003: Ceramic standardization and intensity of production: quantifying degrees of specialization, American Antiquity 68, No. 4., 768-782. https://doi.org/10.2307/3557072

ROUX, V.-CORBETTA, D., 1989: The potter's wheel. Craft specialization and technical competence. New Delhi - Bombay - Calcuta.

SHEPARD, A. O., 1956: Ceramics for the archaeologist. Washington.

ŠAUROVÁ, D., 1982: Výzkum dehtářských pecí na výrobu kolomazi. In: Zkoumání výrobních objektů a technologií archeologickými metodami 2, 33-47. Brno.

VERMOUZEK, R., 1983: Stř̌edověký vůz - Der Wagen im Mittelalter, AH 8, 311-325.

- 1984: Kování středověkého vozu. In: Zkoumání výrobních objektů a technologií archeologickými metodami 3, 110-122. Brno.

WINTER, Z., 1906: Dějiny řemesel a obchodu v Čechách v XIV. a XV. století. Praha. 
WOITSCH, J., 2012: Tradiční výroba dehtu a kolomazi: od dehtářských jam k dvoupláštovým pecím, Archeologia technica 23, 83-90.

ZIMOLA, D., 2013: Archeologie na hranicích - pravěké až raně novověké dějiny jižních Čech, Vysočiny, jižní Moravy a Dolního Rakouska. Katalog k výstavě. Havlíčkův Brod.

\section{Internetové zdroje}

Indian pottery it's amazing, Youtube, https:/www.youtube.com/watch?v=2myC08IsZyA, cit. 13. 7. 2017. YLD - Yvon Le Douget - Céramiste, https://ledouget.fr/\#docs_noron; https://ledouget.fr/\#!/autrefois-en-bretagne-les-potieres-de-saint-jean, cit. 13. 7. 2017.

\section{Zusammenfassung}

\section{Das in Vergessenheit geratene schnell drehende Töpferrad}

In den Bildquellen ist ab dem 13. Jahrhundert die Verwendung von schnell drehenden Töpferrädern belegt, wobei sie in einigen Ländern bis heute Verwendung finden (z.B. in Indien; Abb. 3-4, Quellenverzeichnis in Tabelle 1). Von der tschechischen Forschung wird diese Gruppe Töpferscheiben immer noch stiefmütterlich behandelt, im Ausland wird ihr bereits Raum gewidmet. Man kann nicht umhin, die umfangreiche Arbeit von Alice Kaltenberger zu erwähnen (2009, 180-181, 318-322, Abb. 128-140), für Deutschland dann den Artikel von Caroline Leterme (2008) und für Frankreich etwa das Werk von Rémy Guadagnin (2007). Mit Rekonstruktionen von Töpferrädern beschäftigt man sich im Rahmen von experimentellen archäologischen Projekten bzw. Workshops (etwa auf der französischen Burgbaustelle Guédelon und in deren handwerklichem Umfeld, siehe Martin-Renucci 2016).

Diese Art Töpferscheibe besteht aus zwei Hauptteilen. Auf eine senkrecht im Boden eingelassene, oben zugespitzte Tragachse wurde waagerecht zur Erde eine Radfelge gesetzt, deren oberer Rand als Drehscheibe hergerichtet wurde (Abb. 2). Die Herstellung der Radfelge ist ein komplizierter handwerklicher Prozess und wurde wahrscheinlich nicht von den Töpfern selbst, sondern von Radmachern durchgeführt.

Nachdem die Töpfermasse auf die Drehscheibe gelegt wird, versetzt man das Rad mit einem am oberen Teil der Radfelge oder an der Verbindung zwischen Felge und Radspitze befestigten Stock in Drehung. Das Rad wurde zumeist von dem Handwerker selbst angetrieben, allerdings sind in den historischen Quellen auch Helfer belegt. Für spezielle Arbeitsschritte, die eine geringe Drehzahl erfordern, wie etwa die Endmodellierung, kann die Scheibe auch nur mit der Hand gedreht werden.

Zwecks höherer Sicherheit für den Töpfer konnte das Töpferrad auch in eine Holzrahmenkonstruktion eingesetzt werden, ggf. fanden Fußhocker Verwendung. Die Überreste von Töpferradstrukturen für schnell drehende Töpferscheiben mit einer wahrscheinlichen Rahmenkonstruktion sind im belgischen Raeren belegt. Durch eine archäologische Grabung wurden dort in zwei aus der Zeit der Wende des Mittelalters zur frühen Neuzeit stammenden Töpferarealen drei in der Erde eingetiefte, ausgemauerte Töpferradstrukturen entdeckt (Leterme 2008).

Bislang einzeln stehend ist die Darstellung eines auf einem Tisch aufgebauten und mit der Hand angetriebenen Töpferrades (Abb. 3:P).

Um die Arbeitsmöglichkeiten auszuprobieren wurde aus einem zur Entsorgung bestimmten alten Rad ein Töpferrad experimentell hergestellt. Dabei wurde die einfachste Konstruktion gewählt, bei welcher die Achse des Töpferrades direkt in der Erde verankert wurde. Die Grube wurde mit trocken aufeinander geschichteten Steinen und mit Schotter verfüllt. Mit dem Experiment wurde nachgewiesen, dass sich mit einem solchen Töpferrad die gleichen Ergebnisse erzielen lassen wie mit einer schnell drehenden, mit dem Fuß angetriebenen Töpferscheibe. Wichtig 
dabei ist jedoch, dass der Zubereitung der Töpfermasse genügend Aufmerksamkeit gewidmet werden sollte.

Mgr. Pavel Macků, Národní památkový ústav, ÚOP v Telči, Hradecká 6, 58856 Telč, Česká republika, macku.pavel@npu.cz 
